\title{
EDITORIAL $^{\mathrm{I}}$
}

Estamos iniciando mais um número da Revista Brasileira de Educação Especial com 10 artigos inéditos, com procedência dos estados de São Paulo, Minas Gerais, Paraíba, e distrito Federal, Brasília. O número 1, do volume 22 de 2016, também conta com um artigo oriundo de Portugal.

Esses artigos estão distribuídos em três seçóes: Ensaio, composto por dois artigos; Relato de Pesquisa, com seis textos; e Revisão da literatura, com dois manuscritos.

Os temas são bastante variados. O primeiro artigo na Seção Ensaio apresenta uma análise crítica da legislação sobre as políticas públicas em relação a educação inclusiva de alunos na faixa etária de 0 a 3 anos. A busca na legislação teve o intuito de compreender como a creche é tratada nesses documentos e verificar a existência de indicativos do atendimento especializado a essas crianças.

O segundo artigo dessa seção traz uma interessante análise sobre o transporte acessível, mais especificamente os ônibus escolares para estudante com deficiência, tendo como material para análise o Plano Viver Sem Limites do Governo Federal. Os autores tomam como referência a Meta 4 e a Estratégia 4.6 do novo Plano Nacional de Educação.

Na seção de Relato de Pesquisa, o primeiro artigo tem com meta analisar a eficácia de um programa de treino de trampolins na proficiência motora de crianças com transtorno do espectro do autismo. O programa, desenvolvido em Portugal, teve uma duração de 20 semanas e contou com a participaçáo de 17 sujeitos de pesquisa.

O segundo artigo dessa seção buscou investigar as dificuldades e sucessos de professores de Educação Física para a inclusão escolar de alunos com deficiência e autismo. A pesquisa foi realizada por meio do filmagens e cuja análise classificou os dados em termos de seleção do conteúdo a ser ministrado, da estratégia de ensino, do recurso pedagógico.

O terceiro texto da seção Relato de Pesquisa apresenta um estudo sobre a representação cultural da deficiência nos discursos midiáticos do Portal do Professor do MEC. A análise fundamentou-se na perspectiva foucaultiana de análise arqueológica do discurso.

O quarto manuscrito conta a história de vida de líderes surdos a partir da suas trajetórias em movimentos sociais. Foi realizado por meio de entrevistas abertas e semiestruturadas.

Os dois artigos, que fecham essa seção, têm como tema a Educação Física e o esporte. $\mathrm{O}$ primeiro apresenta uma pesquisa sobre o ensino de futsal para pessoas com deficiência intelectual. O segundo coletou as percepções do aluno com deficiência em relação à Educação Física.

${ }^{1}$ http://dx.doi.org/10.1590/S1413-65382216000100001 
A seção Revisão da Literatura é composta por dois artigos. Um estuda as características e tendências das teses em Educação Especial desenvolvidas nos programas de pós-graduação em educação do estado de Sáo Paulo. O outro realiza um levantamento dentro do tema "Habilidades matemáticas e as pessoas com deficiência intelectual”.

Boa leitura a todos!

Eduardo José Manzini (Unesp) Débora Regina de Paula Nunes (UFRN)

Dirce Shizuko Fujisawa (UEL)

Fabiana Cia (UFSCar)

Márcia Denise Pletsch (UFRRJ)

Editores 